\begin{tabular}{|l|l|l||}
\hline \multicolumn{2}{|c|}{ PublisherInfo } \\
\hline \hline PublisherName & $:$ & BioMed Central \\
\hline \hline PublisherLocation & $:$ & London \\
\hline \hline PublisherImprintName & $:$ & BioMed Central \\
\hline \hline
\end{tabular}

\title{
Automated external defibrillators
}

\begin{tabular}{|l|l|l||}
\hline \multicolumn{2}{|c||}{ ArticleInfo } \\
\hline \hline ArticleID & $:$ & 4180 \\
\hline \hline ArticleDOI & $:$ & $10.1186 /$ ccf-2000-2701 \\
\hline \hline ArticleCitationID & $:$ & 2701 \\
\hline \hline ArticleSequenceNumber & $:$ & 39 \\
\hline \hline ArticleCategory & $:$ & Paper Report \\
\hline \hline ArticleFirstPage & $:$ & 1 \\
\hline \hline ArticleLastPage & $:$ & 3 \\
\hline \hline & & RegistrationDate : 2000-12-6 \\
\hline ArticleHistory & $:$ & OnlineDate \\
\hline \hline ArticleCopyright & $:$ & Current Science Ltd2000-12-6 \\
\hline \hline ArticleGrants & $:$ & \\
\hline \hline ArticleContext & $:$ & 1305422 \\
\hline \hline
\end{tabular}




\section{Keywords}

\section{Comments}

The automated external defibrillator (AED) appears to be an effective device for the treatment of cardiac arrest in an environment remote from medical care, where contributing factors (stress of travel, reduced oxygen tension in flight, and disruption of circadian rhythms) may exacerbate underlying pathology. Reassuringly, its specificity was $100 \%$ in those conscious patients whose rhythm was not ventricular fibrillation (VF) and where the AED was being used as a monitoring device. Interestingly, another paper in the same issue of the journal (see Additional information), reports the experiences of security guards using the device in casinos. Presumably, enthusiasts would like to see AEDs in all public places in the future, enabling successful defibrillation to become routinely performed by the public. Perhaps a convenient location for AEDs would be alongside cash-point machines in the high street, which may also become a high-stress environment following a review of one's bank-balance!

\section{Introduction}

Rapid defibrillation following cardiac arrest is the major determinant of survival, and so schemes allowing public access to defibrillators have been implemented in the USA. AED may improve the simplicity of defibrillation by the public. American Airlines now has an AED on all flights; an environment where a rapid medical emergency response is not possible. In this and similar locations the AED may have a very positive impact on outcome.

\section{Methods}

Review of arrhythmia and outcome in 200 persons where the AED was utilised on American Airlines aircraft between June 1997 and July 1999. 


\title{
Results
}

The AED was used on 191 people aboard the aircraft, and nine in the terminal. Electrocardiograph (ECG) data were available for 185 patients and defibrillation was advised in 14 patients (all with ECG evidence of VF). Defibrillation was not advised in the remainder, giving a sensitivity and specificity of $100 \%$ in identifying VF. Survival to hospital discharge following defibrillation was $40 \%$. The use of the AED as a monitoring device in conscious patients resulted in no complications.

\section{Additional information}

\author{
Valenzuela TD, Roe DJ, Nichol G, Clark LL, Spaite DW, Hardman RG: Outcomes of rapid
}

defibrillation by security officers after cardiac arrest in casinos. $N$ Engl $J$ Med 2000, 343:1206-1209.

\section{References}

1. Page RL, Joglar JA, Kowal RC, Zagrodzky JD, Nelson LL, Ramaswamy K, Barbera SJ, Hamdan MH, McKenas DK: Use of automated external defibrillators by a US airline. N Engl J Med. 2000, 343: 1210-1216. 